Counsellia: Jurnal Bimbingan dan Konseling 8 (1), 45 - 52 | Mei 2018

Copyright $@ 2017$ Universitas PGRI Madiun

ISSN: 2088-3072 (Print) / 2477-5886 (Online)

Available online at: http://e-journal.unipma.ac.id/index.php/JBK

DOI: 10.25273/counsellia.v8i1.1868

\title{
Prokrastinasi Akademik Dikalangan Mahasiswa Program Studi Bimbingan dan Konseling
}

\author{
Siti Muyana \\ Fakultas Keguruan dan Ilmu Pendidikan, Universitas Ahmad Dahlan, Yogyakarta \\ siti.muyana@bk.uad.ac.id
}

\begin{abstract}
Abstrak
Prokrastinasi akademik merupakan perilaku menunda-nunda mengerjakan ataupun menyelesaikan tugas-tugas akademik. Penelitian ini bertujuan memberikan gambaran mengenai prokrastinasi akademik yang dialami oleh mahasiswa. Penelitian ini merupakan jenis penelitian deskriptif dengan pendekatan kuantitatif. Penelitian ini menggunakan alat pengumpul data berupa skala prokrastinasi akademik. Subyek yang digunakan dalam penelitian ini adalah mahasiwa prodi BK sejumlah 229 mahasiswa yang di ambil dengan cara simple random sampling. Analisis data dalam penelitian ini menggunakan teknik persentase. Hasil yang diperoleh dalam penelitian ini menggambarkan kondisi prokrastinasi akademik mahasiswa pada kategori sangat tinggi sebesar 6\%, kategori tinggi $81 \%$, kategori sedang $13 \%$, kategori rendah $0 \%$. Prokrastinasi akademik yang dialami oleh mahasiswa tersebut terdiri dari beberapa aspek antara lain keyakinan akan kemampuan, ganggaun perhatian, faktor sosial, manajemen waktu, inisiatif, pribadi, dan kemalasan.
\end{abstract}

Kata kunci: prokrastinasi akademik, behaviour, tugas akademik

\begin{abstract}
Academic procrastination is a procrastinating behavior of doing or completing academic tasks. This study aims to provide an overview of the academic procrastination experienced by students. This research is a descriptive research with quantitative approach. This study uses data collection tool in the form of academic procrastination scales. The subjects used in this study are students of guidance and counseling program of 229 students taken by simple random sampling. Data analysis in this research using percentage technique. The results obtained in this study describes the condition of student academic procrastination in very high category of $6 \%$, high category $81 \%$, medium category $13 \%$, low category $0 \%$. The academic procrastination experienced by the student consists of several aspects such as belief in ability, attention disturbance, social factors, time management, initiative, personal, and laziness.
\end{abstract}

Keywords: academic procrastination, behavior, academic task 


\section{PENDAHULUAN}

Sebagian orang memandang menunda tugas sebagai suatu prilaku negatif. Orang yang menunda tugas dianggap tidak peduli dengan kualitas tugas dan memiliki kemampuan kognitif yang lebih rendah dibanding kelompoknya. Hasil studi empiris oleh Burns, Dittman, Nguyen, \& Mitchelson (2000) dan Wolters (2003) mengungkapkan hasil dari menundanunda bahwa seseorang akan kehilangan waktu, kesehatan yang terganggu, dan harga diri yang rendah. Pada sebuah penelitian yang dilakukan oleh Ferrari \& Tice (2000), prokrastinasi atau menunda-nunda dapat dikatikan dengan kecemasan dan ketakutan terhadap kegagalan. Menunda-nunda dianggap sebagai hambatan mahasiswa dalam mencapai kesuksesan akademis karena dapat menurunkan kualitas dan kuantitas pembelajaran, menambah tingkat stres, dan berdampak negatif dalam kehidupan mahasiswa.

Dampak yang terjadi akibat prokrastinasi akademik seringkali tidak menjadi perhatian khusus bagi sebagian mahasiswa. Kondisi tersebut ditunjukkan dari beberapa hasil penelitian yang menunjukkan tingkat prokrastinasi akademik mahasiswa masih cenderung tinggi. Burka \& Yuen (2008) memperkirakan prokrastinasi pada mahasiswa mencapai $75 \%$, dengan $50 \%$ dari siswa melaporkan bahwa mereka prokrastinasi konsisten dan menganggapnya sebagai masalah. Hasil penelitian Yudistiro (2016:428) diketahui siswa yang memiliki prokrastinasi akademik tinggi dan sangat tinggi dengan jumlah 4 siswa atau sekitar 7.55 persen di kategori sangat tinggi dan 17 siswa atau 32,08 persen di kategori tinggi. Dalam kategori ini, siswa cenderung selalu menunjukan perilaku penundaan mengerjakan tugas akademik sebagai suatu pegunduran secara sengaja dan biasanya disertai dengan perasaan tidak suka untuk megerjakan sesuatu yang harus dikerjakan. Mahasiswa yang melakukan prokrastinasi akademik diprediksi sangat sedikit yang memanfaatkan tenggang waktu yang diberikan untuk menyelesaikan tugas. Penundaan yang tidak disertai dengan peran adaptif mahasiswa dapat menyebabkan mahasiswa kurang berprestasi (Schraw, Watkinds, \& Olafson, 2007).

Berbagai fenomena yang dijelaskan oleh ahli tersebut menjadi dasar pemikiran dalam penelitian ini. Tujuan utama dalam penelitian ini dalah untuk dapat memberikan penjelasan deskriptif yang lebih mendalam tentang prokrastinasi akademik di kalangan mahasiswa. Prokrastinasi akademik perlu untuk diketahui agar dapat dilakukan upaya pencegahan terjadinya prokrastinasi akademik yang berkepanjangan pada mahasiswa. Hasil penelitian ini dapat dijadikan sebagai informasi bagi konselor perguruan tinggi sebagai acuan dalam upaya membantu mahasiswa mengembangkan kemampuan di bidang akademik dan meminimalisir permasalahan yang muncul akibat prokrastinasi akademik.

\section{KAJIAN LITERATUR}

Tugas merupakan suatu bentuk kegiatan yang harus diselesaikan oleh masing-masing individu yang bersangkutan. Pada setiap tugas individu yang berbeda, akan ada respon yang berbeda-beda juga dalam menyikapinya. Ferrari (Nugrasanti, 2006: 26) 
mengemukakan bahwa menunda tugas akademik disebut dengan prokrastinasi akademik, yaitu suatu perilaku untuk menunda-nunda mengerjakan ataupun menyelesaikan tugas-tugas akademik. Perilaku tersebut dapat dilihat pada siswa yang menunda-nunda untuk memulai atau menyelesaikan tugas atau pekerjaan rumah, menyerahkan tugas melewati batas waktu, menunda untuk membaca bahan pelajaran, malas untuk membuat catatan, terlambat masuk kelas dan cenderung lebih suka belajar pada malam terakhir menjelang ujian. Pendapat mengenai prokrastinasi akademik selanjutnya dikemukakan oleh Wolter (2003) bahwa "prokrastinasi akademik merupakan kegagalan dalam mengerjakan tugas akademik dalam kerangka waktu yang diinginkan atau menunda mengerjakan tugas sampai saat-saat terakhir". Prokrastinasi akademik dipahami sebagai suatu perilaku yang menjadi kebiasaan yang tidak efektif dan cenderung ke arah negatif dalam menunda-nunda pekerjaan. Prokrastinasi yang berkepanjangan tentu dapat mengganggu proktivitas individu dan dapat mengganggu kondisi individu secara psikis.

Berbagai bentuk prokrastinasi dapat dilakukan oleh siapapun dan dapat dilakukan pada semua jenis pekerjaan. Ferrari, Johnson, \& Mc Cown (1995) membagi prokrastinasi menjadi dua jenis, antara lain:

1) Functional procratinasi merupakan menunda pekerjaan atau tugas dengan tujuan untuk memperoleh informasi yang lebih akurat.

2) Dysfunctional procrastinasi yaitu menunda pekerjaan atau tugas tidak berdasarkan tujuan, berakibat buruk dan menimbulkan masalah. Ada dua jenis dysfunctional procrastinasi berdasarkan tujuan melakukan penundaan yaitu: desisional procrastination adalah suatu penundaan dalam mengambil keputusan, merupakan suatu coping untuk menghindari kemungkinan stres dan menyesuaikan diri dalam pembuatan keputusan yang dipresepsikan penuh stres. Desisional procrastination berhubungan dengan kelupaan, kegagalan proses kognitif, akan tetapi tidak berkaitan dengan kurangnya tingkat intelegensi seseorang. Jenis yang kedua dari dysfunctional procrastination adalah evoidance procrastination dan behavioral procrastination yang merupakan suatu penundaan dalam perilaku yang tampak. Penundaan dilakukan untuk menghindari tugas yang dirasa tidak menyenagkan dan sulit untuk dilakukan.

Spesifikasi prokrastinasi akademik menurut Millgram (Ferrari, Johnson, \& McCown, 1995) merupakan perilaku spesifik yang meliputi: (1) suatu perilaku yang melibatkan unsur penundaan baik saat memulai maupun menyelesaikan suatu tugas; menghasilakan akibat-akibat yang lebih jauh, seperti keterlambatan menyelesaikan tugas, atau kegagalan dalam mengerjakan tugas; (3) melibatkan suatu tugas yang dipresepsikan oleh pelaku prokrastinasi sebagai suatu tugas yang penting untuk dikerjakan, misalnya tugas kantor, sekolah maupun rumah tangga; (4) menghasilkan keadaan emosional yang tidak menyenangkan, misalnya perasaan cemas, panik,bersalah, marah dan sebagainya. Prokrastinasi akademik di 
kalangan mahasiswa banyak terjadi aktivitas penundaan, seperti membuat paper atau menulis, penundaan tugas belajar menghadapi ujian, tugas membaca, kinerja tugas akademik, dan menghadiri perkuliahan. Menurut Ferrari, Johnson, \& McCown (1995) terdapat beberapa ciri-ciri prokrastinasi akademik meliputi: 1) penundaan dalam memulai maupun menyelesaikan tugas yang dihadapi; 2) keterlambatan mengerjakan tugas; 3) kesenjangan waktu antara rencana dan kinerja aktual; 4) melakukan aktivitas lain yang lebih menyenangkan daripada melakukan tugas yang harus dikerjakan. Selanjutnya menurut Mccloskey (2011) karakteristik prokrastinasi akademik antara lain: keyakinan psikologis tentang kemampuan (tantangan dan tekanan), gangguan, faktor sosial, manajemen waktu, inisiatif pribadi dan kemalasan.

Munculnya prokrastinasi

akademik dalam diri mahasiswa diprediksi tidak terjadi begitu saja, namun terdapat penyebab yang melatarbelakangi. Menurut Ferrari, Johnson, \& Mc Cown (1995) menyebutkan bahwa penyebab perilaku prokrastinasi adalah:

1) Adanya pikiran irrasional dari prokrastinator, yaitu anggapan bahwa suatu tugas harus diselesaikan dengan sempurna.

2) Adanya kecemasan karena kemampuannya dievaluasi, ketakutan akan kegagalan dan susah mengambil keputusan, atau karena membutuhkan bantuan orang lain untuk mengerjakan tugasnya.

3) Malas dan kesulitan mengatur waktu dan tidak menyukai tugasnya.

4) Adanya punishment dan reward juga dapat menyebabkan prokrastinasi sehingga merasa lebih aman jika tidak melakukan dengan segera karena dapat menghasilkan sesuatu yang tidak maksimal.

5) Adanya faktor lingkungan, yaitu kurangnya pengamatan dari lingkungan seperti keluarga atau di lingkungan sekolah juga menyebabkan seseorang melakukan prokrastinasi.

6) Selain itu prokrastinasi disebabkan karena tugas yang menumpuk, terlalu banyak dan harus segera dikerjakan, sehingga penundaan tugas yang satu dapat menyebabkan tugas lain tertunda.

Banyaknya ahli yang memberikan pendapat terkait dengan konsep prokrastinasi akademik, peneliti menyimpulkan prokrastinasi akademik merupakan penundaan dalam memulai maupun menyelesaikan tugas yang dihadapi sehingga mengalami keterlambatan dalam mengerjakan tugas akademik dalam jangka waktu yang diinginkan atau menunda mengerjakan tugas sampai saat-saat terakhir. Karakteristik prokrastinasi akademik yang dimaksud dalam penelitian ini berupa keyakinan psikologis tentang kemampuan (tantangan dan tekanan), gangguan, faktor sosial, manajemen waktu, inisiatif pribadi dan kemalasan.

\section{METODE PENELITIAN}

Penelitian ini merupakan jenis penelitian deskriptif dengan pendekatan kuantitatif. Penelitian ini bertujuan untuk memberikan penjelasan deskriptif yang lebih mendalam tentang prokrastinasi akademik di kalangan mahasiswa. Subyek yang digunakan dalam penelitian ini adalah mahasiwa prodi BK sejumlah 229 mahasiswa yang 
di ambil dengan cara simple random sampling. Teknik pengumpulan data dalam penelitian ini menggunakan teknik nontes dengan instrumen berupa skala prokrastinasi akademik dengan empat kategori jawaban, yaitu sangat sesuai, sesuai, kurang sesuai, dan tidak sesuai. Selanjutnya, analisis data dalam penelitian ini menggunakan rumus persentase agar memperoleh gambaran mengenai kondisi prokrastinasi yang dialami mahasiswa.

\section{HASIL DAN PEMBAHASAN}

Hasil analisis data prokrastinasi akademik mahasiswa secara umum dikateogorisasikan menjadi beberapa kategori. Adapun profil prokrastinasi akademik mahasiswa prodi BK dapat dilihat pada tabel 1 berikut ini.

Tabel 1

Distribusi Frekuensi Prokrastinasi

Akademik Mahasiswa Prodi BK

\begin{tabular}{ccc}
\hline Kategori & Interval & F \\
\hline Sangat Tinggi & $104-128$ & 3 \\
Tinggi & $80-103$ & 161 \\
Rendah & $56-79$ & 65 \\
Sangat Rendah & $32-55$ & 0 \\
Total & & 229 \\
\hline
\end{tabular}

Pada tabel 1 diketahui bahwa dari jumlah total 229 mahasiswa, terdapat sejumlah 3 mahasiswa yang memiliki prokrastinasi akademik pada kategori sangat tinggi dan 161 mahasiswa yang berada pada kategori tinggi. Mahasiswa yang memiliki prokrastinasi rendah sebanyak 65 mahasiswa dan tidak ada mahasiswa yang memiliki prokrastinasi pada kategori sangat rendah. Hasil analisis tersebut menunjukkan bahwa kategori terbanyak terkait dengan prokrastinasi akademik mahasiswa berasa pada kategori tinggi, yaitu sejumlah 161 mahasiswa. Data prokrastinasi akademik mahasiswa yang telah terkumpul melalui skala prokrastinasi akademik, selanjutnya dilakukan analisis dengan menggunakan rumus persentase. Berdasarkan hasil analisis data diperoleh rincian gambaran mengenai kondisi prokrastinasi akademik yang dialami oleh mahasiswa BK. Gambaran prokrastinasi akademik dapat diketahui melalui gambar 1 berikut ini.

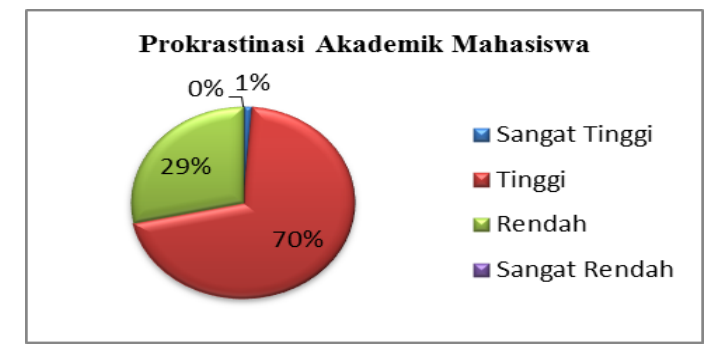

Gambar 1

Persentase Prokrastinasi Akademik Mahasiswa Prodi BK

Berdasarkan hasil persentase prokrastinasi akademik tersebut dapat diketahui bahwa sebagian besar mahasiswa memiliki prokrastinasi akademik pada kategori tinggi sebesar $70 \%$. Jika dibandingkan dengan kategori lain, kategori tinggi ini lebih mendominasi kondisi prokrastinasi akademik mahasiswa prodi BK. Sebaliknya, tidak ada mahasiswa yang tidak memiliki kondisi prokrastinasi akademik yang berada pada kategori sangat rendah. Idealnya kondisi sangat rendah inilah yang seharusnya dikembangkan oleh mahasiswa prodi BK. Kenyataanya, hasil analisis dari data yang diperoleh menunjukkan hanya 29\% mahasiswa yang memiliki kondisi prokrastinasi akademik pada kategori rendah.

Agar lebih jelas, berikut ini dipaparkan mengenai prokrastinasi 
akademik mahasiswa pada masingmasing indikator yang dapat dilihat pada tabel 2 berikut ini.

Tabel 2

Persentase Prokrastinasi Akademik pada Masing-masing Indikator

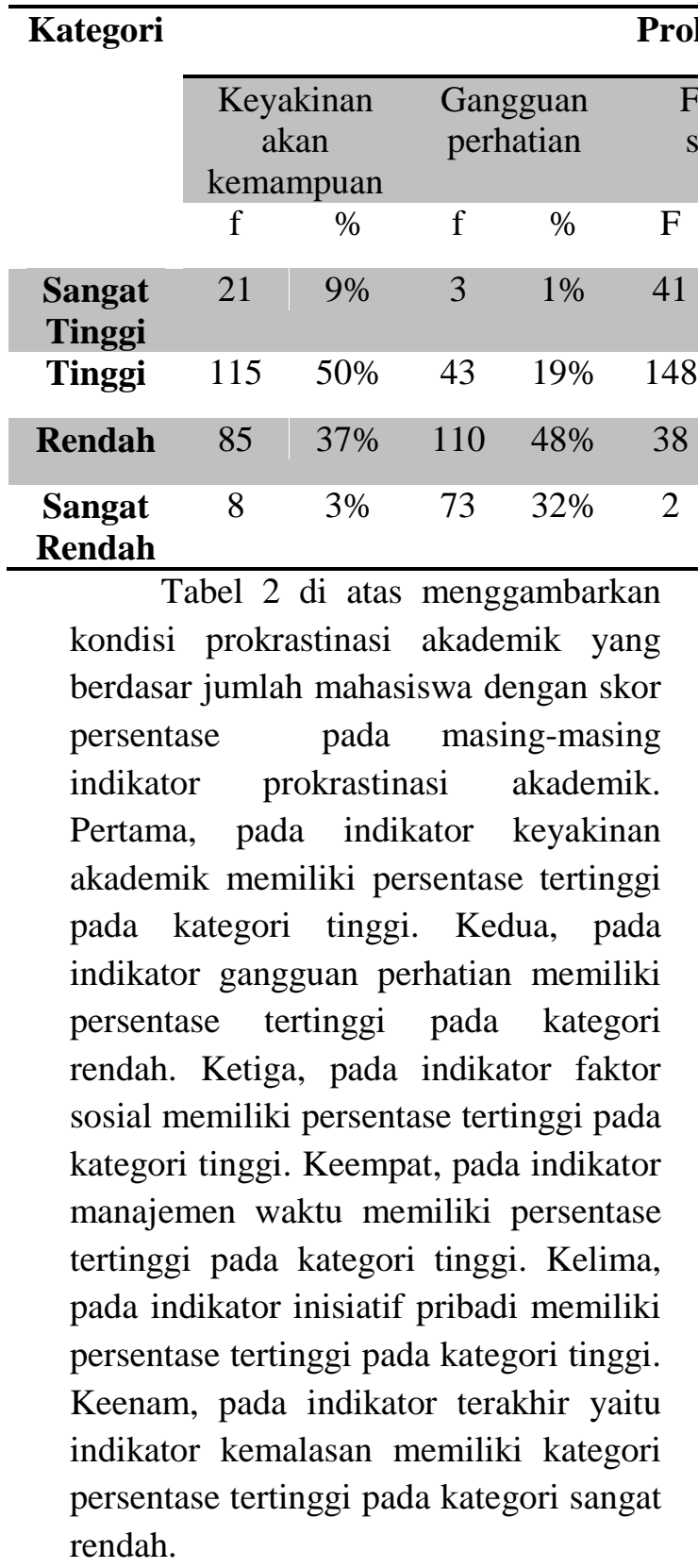

Berdasarkan pada data persentase prokrastinasi akademik mahasiswa pada tabel 2 dimaknai bahwa prokrastinasi akademik yang paling banyak terjadi pada mahasiswa terdapat pada indikator manajemen waktu dengan persentase
$21 \%$ atau sebanyak 47 dari 229 mahasiswa dengan kategori sangat tinggi. Prokrastinasi akademik paling sedikit dialami mahasiswa terdapat pada indikator gangguan perhatian dan kemalasan dengan besaran persentase sama, yaitu sebesar $1 \%$ atau sebanyak 3 dari 229 mahasiswa.

Deskripsi selanjutnya mengenai persentase prokrastinasi akademik mahasiswa pada masing-masing indikator secara lebih detail disajikan dalam gambar 2 berikut ini.

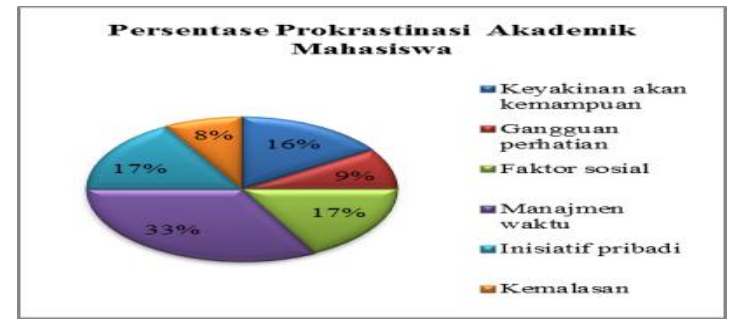

Gambar 2

Persentase Prokrastinasi Akademik Mahasiswa pada Masing-masing Indikator

Hasil analisis gambar 2 dapat dijelaskan sebagai berikut:

1. Keyakinan akan kemampuan 
Kemampuan individu dalam menjalankan tugas akademik seringkali di pengaruhi oleh keyakinan yang dimiliki. Dalam hal ini keyakinan masuk dalam konsep diri mahasiswa, yakni bagaimana mahasiswa memandang akan kemampuan dirinya dalam penyelesaian tugas-tugas akademik. Keyakinan mahasiswa akan kemampuan diri memberi kontribusi terhadap prokrastinasi akademik sebesar $16 \%$.

2. Gangguan perhatian

Pemusatan akan perhatian terhadap suatu objek tentu membutuhkan konsentrasi penuh. Apabila tidak terpenuhi maka akan memunculkan kesulitan untuk berkonsentrasi akibat adanya gangguan-gangguan dari berbagai faktor, baik faktor secara internal ataupun eksternal. Pada penelitian ini gangguan perhatian memberikan kontribusi sebesar 9\% terhadap prokrastinasi akademik mahasiswa.

3. Faktor sosial

Kemampuan dalam bersosialisasi adalah faktor penting dalam menjalani kehidupan. Permasalahan terkait dengan faktor sosial seringkali akan berpengaruh terhadap hal lain, salah satunya prokrastinasi. Pada panelitian ini, faktor sosial memberikan kontribusi sebesar $17 \%$ terhadap prokrastinasi akademik mahasiswa.

4. Manajemen waktu

Kemampuan mahasiswa dalam mengelola waktu cenderung menjadi kontribusi terbesar dalam prokrastinasi akademik mahasiswa. Hal tersebut dibuktikan dari hasil penelitian ini bahwa manajemen waktu memberikan kontribusi sebesar $33 \%$ terhadap prokrastinasi akademik mahasiswa.

5. Inisiatif pribadi

Keputusan dalam menjalani kehidupan seyogyanya ada pada masing-masing individu. Inisiatif pribadi merupakan kemampuan individu dalam memutuskan sesuatu yang benar tanpa harus diberi tahu oleh orang lain. Inisiatif pribadi dalam penelitian ini memberikan kontribusi sebesar $17 \%$ terhadap prokrastinasi akademik masaiswa.

6. Kemalasan

Tidak ingin atau belum termotivasi untuk melakukan apapun termasuk menyelesaikan tugas-tugas akademik juga merupakan kendala mahasiswa. Oleh karenanya, kemalasan juga berkontribusi dalam prokrastinasi akademik mahasiswa sebesar $8 \%$.

\section{KESIMPULAN}

Penelitian ini merupakan penelitian yang dilakukan di kalangan mahasiswa. Hasil penelitian menggambarkan bahwa prokrastinasi akademik di kalangan mahasiswa cenderung menunjukkan kategori tinggi. Mahasiswa yang memiliki kecenderungan berprilaku prokrastinasi akademik diidentifikasi melalui berbagai indikator prokrastinasi akademik antara lain keyakinan akan kemampuan, gangguan perhatian, faktor sosial, manajemen waktu, inisiatif pribadi, dan kemalasan. Hasil penelitian ini dapat dijadikan sebagai informasi bagi konselor perguruan tinggi sebagai acuan dalam upaya membantu mahasiswa mengembangkan kemampuan di bidang akademik dan meminimalisir 
permasalahan yang muncul akibat prokrastinasi akademik.

\section{DAFTAR PUSTAKA}

Burka, J. B. \& Yuen, L. M. (2008). Procrastination: Why You Do It, What To Do About It. Camridge: Da Capo Press.

Burns, L. R., Dittman, K., Nguyen, N., \& Mitchelson, J. K. (2000). Academic procrastination, perfectionism, and control: Associations with vigilant and avoidant coping. Journal of Social Behavior and Personality, 5, 35-46.

Ferrari, J. R., Johnson, J. L., \& McCown, W. G. (1995). Procrastination and task avoidance: Theory, research, and treatment. New York: Plenum Press.

Ferrari, J., \& Tice, D. (2000). Procrastination as a selfhandicap for men and women: A task-avoidance strategy in a laboratory setting. Journal of Research in Personality, 34, 7383.

Mccloskey, j.d. (2011). Finally, My Thesis on Academic Procrastination. Thesis tidak diterbitkan. The University of Texas at Arlington.

Nugrasanti, Reni. (2006). Locus of Control dan Prokrastinasi Akademik Mahasiswa; Jurnal Provitae 2 No 1, Mei 2006. Jakarta: Yayasan Obor Indonesia.

Schraw, G., Watkinds, T., \& Olafson, L. (2007). Doing the Things We Do: A Grounded Theory of Academic Procrastination. Journal of Educational Psychology, 2007, Vol. 99, No. $1,12-25$.

Wolters, C. A. (2003). Understanding Procrastination from a
Selfregulated Learning Perspective. Journal of Educational Psychology, 95, $179-187$.

Yudistiro. (2016). Hubungan Prokrastinasi Akademik dengan Prestasi Belajar pada Siswa yang Aktif dalam Kegiatan Ekstrakurikuler. Psikoborneo, 4 (2): 425-431. 